ISBN 978-93-84422-79-0

7th International Conference on Business, Education, Law, and Sustainable Development

(BELSD-17)

Singapore Aug. 10-11, 2017

\title{
Functionalization of Criminal Law in Tackling May 1998 Mass Violence
}

\author{
Rehnalemken Ginting ${ }^{1}$, Adi Sulistiyono ${ }^{2}$ and Hartiwiningsih ${ }^{3}$ \\ ${ }^{1}$ Doctorate Candidate at Law Faculty, Sebelas Maret University, Surakarta \\ ${ }^{2}$ Promoter, Professor of Law, Lecuturer at Sebelas Maret University, Surakarta \\ ${ }^{3}$ Co-promoter, Professor of Law, Lecturer and Director of Program of Jurisprudence Doctor, \\ Sebelas Maret University, Surakarta
}

\begin{abstract}
The predicate or title given to the event of May 1998 such as riot, tragedy, calamity, ferocity, mass amok is actually the violence perpetrated by the masses against people and goods that fall within the realm of criminal law. The cause of this violence was the impact of the rulers' incompetence at that time in organizing the government, resulting in monetary, economic, and political crises and spread to other crises.This study linked pure research to applied research to solve practical social problems. Within the framework of criminal law modern science, a juridical-criminological approach, a statute approach, a conceptual approach and a historical approach are used. In handling May 1998 mass violence occurred in Surakarta, the article applied is Article 363 paragraph 1 to 4 of Criminal Code which mentioned about seven years at maximum imprisonment, which then linked to Article 55 line 1 of the Criminal Code
\end{abstract}

Keywords: law, criminal, may1998, society

\section{Introduction}

May 1998 mass violence affected both the ruler and the community. There were human victims since there were people injured and died; and the loss of property since it was damaged, destroyed, and even burnt (vehicles such as motorcycles, cars, buses etc.; and buildings such as offices, warehouses, shops, show rooms, houses, etc.) Those included into the realm of criminal law. There are many articles in the Criminal Code (Penal Code) applicable or imposed on the May 1998 mass violence. ${ }^{1}$

May 1998 which mention violence in Article 170 which reads as follows: Paragraph (1) Any person who publicly and by force together using violence against persons or goods, is sentenced to jail about five month. Paragraph (2) The offender shall be threatened: 1st: by at maximum seven years imprisonment, if he/she has the intentiont to destroy the goods or if the violence resulted in injury; 2nd: with a maximum of nine years imprisonment, if violence causes serious injury; 3rd: with a twelve-year long jail sentence, if violence leads to death. Paragraph (3) of Article 89 does not apply to this article.

Furthermore, article 170 of the Criminal Code part 1 and 2 are the most siginificant related to May 1998 mass violence since their element meet all. Paragraph (1) Elements of anyone who is openly and with shared power are fulfilled because May 1998 mass violence committed publicly in mass, the element of using violence occurred where people were persecuted, raped, some even killed, while the goods are met because the building houses, shops, buildings, show room and its contents destroyed, looted, burned, bombed, destroyed.

Paragraph (2) then is a mild categorical severity in relation to the quality of a criminal offense. Paragraph 2 (1) as the first category mention about a maximum imprisonment of seven years, if intentionally destroying the

\footnotetext{
${ }^{1}$ Santoso, Edy Yusuf Nur Samsu. Amuk Massa. Yogyakarta: Alief Press. 2004
} 
goods or if the violence used causes injury. Paragraph 2 (2) as the second category mention about, the violance resulted in several injury got the maximum imprisonment of nine years. While the third as the third category, mention about the maximum imprisonment of twelve years, if violence leads to death. ${ }^{2}$

\subsection{Articles of the Criminal Code}

Other Articles of the Criminal Code related to May 1998 mass violence are contained in, the first is Chapter V on Crimes Against Public Order, as regulated and threatened with criminal sanctions in Articles 154 to Article 157, the second is Chapter VII on Crimes that endanger public safety for persons or goods, as regulated and criminalized in Articles 187, 188, 191-194, 200 and Article 201, the third is Chapter VIII on Crimes Against the Public Authority, as set out and threatened in Article 207, 208, the fourth is Chapter XIV on Crimes Against Decency, which is related to Articles 281, 285-292, the fifth is Chapter XX on the Crime of Persecution, which is related to any criminal sanction in Articles 351-358, the sixth is Chapter XXI on Crimes Causes Anyone to Die or Injure in Forgiveness, as resulted and threatened Criminal in Article 359, 360, the seventh is Chapter XXII on the Evil of theft, as regulated and criminalized in Article $362-367$, the eighth is Chapter XXIII on the Crime of Extortion and Forcla- tion, as set out and threatened with criminal sanctions in Articles 368-371, and the ninth is Chapter XXVII on Crimes Destroying or Destructing Goods, as regulated and criminalized in Articles 406-412.

The May 1998 mass violence resulted in many crimes that could be considered as criminality based on the above articles of the Penal Code. Moreover, the recorded data from the Surakarta City Resort Police showed that there were around 12,000 perpetrators. Only 60 people then examined with 41 witnesses. If we saw the fact, then the number of those who were processed was very small. What about the other 11,940 rioters? Were they out of the legal process? Estimates of 12,000 rioters in the May 1998 riot made by the Surakarta City Resort Police were very unlikely to be in line with the facts, because the rioters were even more intense. ${ }^{3}$

Furthermore, most of the inspection files have to be returned to the Investigator (Police) by the Prosecutor Office because of lack of evidence and witnesses that the case is unlikely to proceed to the Court. Out of sixty suspects, only 15 people whose files were accepted and declared complete by the District Attorney Office of Surakarta. Until August 2002, there were only two perpetrators who became defendants of criminal cases of mass riots on 14 and 15 May 1998 which were tried in the Surakarta District Court. The two cases had permanent legal force as followed: Case No. 241 / Pid. B / 1998 / PN. Ska, and Case No. 284 / Pid. B / 1998 / PN. Ska. Sentenced to criminal under Article 363 paragraph (1) the 2nd, 3rd, 4th KUHP in conjunction with Article 55 Paragraph (1) of the Criminal Code. ${ }^{4}$

\section{Functionalization of Criminal Law in Tackling May 1998 Mass Violence}

In handling May 1998 mass violence occurred in Surakarta, the article applied was Article 363 paragraph 1, 2, 3, and 4 of the Criminal Code which mentioned about imprisonment at maximum seven years: theft in the event of a fire, eruptions, floods, earthquakes, or marine quakes, volcanoes, shipwreck, stranded ships, train accidents, riots, rebellions or war hazards; The theft at night in a home or an enclosed yard by person there in, carried out by a person who is therein is unknown or unwanted by the rightful; Theft committed by two or more persons by alliance, then connected with (juncto is written briefly jo) Article 55 paragraph (1) of the Criminal Code which mention about the penalty for the makers of the criminal act: those who do an who took part. There was also another article that can be used to handle cases of violence mentioned above namely Article 170 of the Criminal Code.

\footnotetext{
${ }^{2}$ Moeljatno, 1978. K.U.H.P. Kitab Undang-Undang Hukum Pidana. Text of Criminal Law. Indonesia: Yogyakarta

${ }^{3}$ Mohammad Jamin, "The Application of Criminal Sanctions for the perpetrators of Mass Unrest 14 - 15 May 1998 (Approach of Legal Sociology Against the Work of Law Enforcement)," Dirjen Dikti Research, . Dept. National Education. Faculty of Law., Sebelas Maret University., Surakarta, Indonesia, 2002. Page 47

${ }^{4}$ Ibid.
} 
The using of Article 363 of the Criminal Code in mass violence where much of the looting seems to be included in the category of theft with theft or theft with qualification and is subject to heavier penalties (not the usual theft as stipulated and criminalized in Article 362 of the Criminal Code). Theft with a weighting is qualified to meet one particular situation, in this mass violence. In fact, in the May 1998 mass violence that occurred not only looting, there was also the use of violence against people (minor injuries, serious injuries, even deaths, some were raped) or goods (destroyed, burned, destroyed) done blatantly and Together, so that the elements in Article 170 of the Criminal Code were all fulfilled.

\section{Obstacle Factors of Functionalization}

The handling of May 1998 mass violence committed by police, prosecutors and judges should be strictly enforced. But in the reality, it could not be handled effectively because of the inhibiting factors such as: First, the dilemmatic condition and situation faced by the law enforcement apparatus was closely related to the political violence of May $1998^{5}$; Second, the psychological obstacles of police officers who did not dare to act decisively, such as shooting in place against the rioters (perpetrators of mass violence), because if it was done there would be mass killings and more human casualties ${ }^{6}$; Third, the empathic attitude of the apparatus towards the perpetrators of mass violence generally derived from the lower classes had experience difficult life, while the masses tend to make non-indigenous people (Chinese descent) as targets ${ }^{7}$; Fourthly, the lack of apparatus compared to the number of masses, according to records from the Surakarta City Police Resort in the May 1998 mob violence estimated the number of perpetrators as many as 12,000 people; Fifth, the difficulty in finding the necessary witnesses in the process of making the BAP, because the small number of apparatus. ${ }^{8}$

Apart from economic problems, politics, human rights or other areas of life, May 1998 mass violence had entered the realm of law, especially criminal law. As the function of law is to protect the public from the threats of harm and harmful actions of peers and groups of society, including those carried out by the holder of power (government and state) and who come from outside, devoted to the physical, life, health, values and human rights. ${ }^{9}$ Referring to the 5th Congress on "Prevention of Crime and Violation of Law" organized by the United Nations agency in September 1975 in Geneva, there were recommendations by expanding the notion of crime against "illegal abuse of economic power", against labor regulations, consumer fraud, violations of environmental regulations, misappropriation of marketing and trade by transnational corporations, violations of tax laws, and against "illegal abuses of public power" such as violations of human rights, abuses of authority by the authorities, such as illegal arrests and detentions. ${ }^{10}$

\section{References}

[1] Moeljatno, 1978. K.U.H.P. Kitab Undang-Undang Hukum Pidana. Text of Criminal Law. Indonesia: Yogyakarta

[2] Mohammad Jamin, "The Application of Criminal Sanctions for the perpetrators of Mass Unrest 14 - 15 May 1998 (Approach of Legal Sociology Against the Work of Law Enforcement),” Dirjen Dikti Research, . Dept. National Education. Faculty of Law., Sebelas Maret University., Surakarta, Indonesia, 2002. Page 47

[3] Thomas Santoso (editor),, in Violence Theories. PT. Ghalia Indonesia Jakarta, 2002, page 5 - 6

[4] Muladi and Barda Nawawi Arief., Ruang Lingkup Penegakan Hukum Pidana dalam Konteks Politik Kriminal. Makalah Seminar Kriminologi V, Semarang: Faculty of Law, Diponegoro University, 11 November, page 7

[5] Tulus Tambunan, Economic Crisis and the Future of Reformation, Faculty of Economic University of Indonesia, Jakarta, 1998, page VII

\footnotetext{
${ }^{5}$ Thomas Santoso (editor)., in Violence Theories. PT. Ghalia Indonesia Jakarta, 2002, page 5 - 6

${ }^{6}$ Muladi and Barda Nawawi Arief., Ruang Lingkup Penegakan Hukum Pidana dalam Konteks Politik Kriminal. Makalah Seminar Kriminologi V, Semarang: Faculty of Law, Diponegoro University, 11 November, page 7

${ }^{7}$ Tulus Tambunan, Economic Crisis and the Future of Reformation, Faculty of Economic University of Indonesia, Jakarta, 1998, page VII

${ }^{8}$ Mody, Nawaz. Indonesia Under Soeharto. New Delhi: Sterling Publisher Private Limited. 1987.

${ }^{9}$ Herbert L Packer., The Limit of Criminal Sanction, California: Standford University Press. 1968, page 17

${ }^{10}$ Bambang Sutiyoso, in Aktualita Hukum dalam Era Reformasi, PT Raja Grafindo Persada Jakarta, 2004, page vii
} 
[6] Herbert L Packer., The Limit of Criminal Sanction, California: Standford University Press. 1968, page 17

[7] Bambang Sutiyoso, in Aktualita Hukum dalam Era Reformasi, PT Raja Grafindo Persada Jakarta, 2004, page vii

[8] Mulyadi, Hadi, dkk. Runtuhnya Kekuasaan "Keraton Alit" (Studi Radikalisme Sosial "Wong Sala" dan Kerusuhan Mei 1998 di Surakarta). Surakarta: Lembaga Pengembangan Teknologi Pedesaan (LPTP). 1989.

[9] Abel, Richard. The Law and Society. New York: New York University Press. 1995

[10] Allen, C.K. Law in The Making. New York: Oxford University Press. 1964

[11] Allot, Antony. The Limits of Law. London: Butterworth \& Co. 1980

[12] Ball, John. Indonesian Legal History 1602 - 1848. Sidney: Oughtshaw Press. 1982.

[13] Bodenheimer, E. Jurisprudence, The Philosophy and Method of Law. Cambridge Mass: Harvard University Press. 1967.

[14] Chang, William. (Head of Pascasarjana STT Pastor Bonus Pontianak). 2004. Dehumanisasi dan Kekerasan Negara. Kompas Monday May 14th 2004.

[15] Dwipayana, G dan R.K. Hadimaja.. Soeharto, Pikiran, Ucapan, dan Tindakan Saya. Jakarta: Citra Lamtoro Gung Persada. 1989

[16] Fletcher, George P. Basic Concepts of Criminal Law. Oxford University Press. 1988

[17] Friedman, John. Planing in the Public Domain: From Knowledge to Action. New Jersey: Princeton University Press. 1987.

[18] Ghazawi, Adami Ghazawi. Pelajaran Hukum Pidana I. Jakarta: PT Raja Grafindo Persada. 2014

[19] Galtung, Johan. The True Worlds: A Transnasional Perspective. New York: The Free Press. 1982.

[20] Jackson, Karl D, and Lucian W. Pye. Political Power and Communication in Indonesia. Berkeley: California University Press. 1978.

[21] Larson, George D. Masa Menjelang Revolusi Kraton dan Kehidupan Politik di Surakarta 1912- 1942. Yogyakarta: Gajah Mada University Press. 1990.

[22] Marzuki, Peter Mahmud. Penelitian Hukum. Jakarta: Kencana. 2005.

[23] Maramis, Frans. Perbandingan Hukum Pidana. Jakarta: Pustaka Sinar Harapan. 1994.

[24] Mody, Nawaz. Indonesia Under Soeharto. New Delhi: Sterling Publisher Private Limited. 1987.

[25] Moeljatno. Azas-Azas Hukum Pidana. Yogyakarta. 1978.

[26] Moh. Mahfud MD. Pergulatan Politik dan Hukum di Indonesia. Yogyakarta: Gama Media. 1999.

[27] Moh. Mahfud MD. Politik Hukum di Indonesia. Indonesia: Pustaka LP3ES. 1998.

[28] Mulyadi, Hadi, dkk. 1989. Runtuhnya Kekuasaan "Keraton Alit" (Studi Radikalisme Sosial "Wong Sala" dan Kerusuhan Mei 1998 di Surakarta). Surakarta: Lembaga Pengembangan Teknologi Pedesaan (LPTP)

[29] Nawawi, Arief Barda. Kapita Selekta Hukum Pidana. Bandung: PT Citra Aditya Bakti. 2003

[30] Prasetyo, Teguh. Hukum Pidana. Jakarta: PT Raja Grafindo Persada. 2011

[31] Pound, Roscoe. Scoupe and Purpose of Sociological Jurisprudence in Harvard Law Review (vol.24 th. 1911, Desember 1911).

[32] Pound, Roscoe. Law Finding through Experience and Reason. University of George Press. 1960.

[33] Rahardjo, Satjipto. Masalah Kebhinekaan Sosial Budaya dalam Reformasi Hukum Nasional menuju Masyarakat Kewargaan. Seminar Hukum Nasional VII Reformasi Hukum Menuju Masyarakat Madani. 12 - 15 Oktober 1999. Jakarta: BPHN Departemen Kehakiman RI

[34] Robertson, Geoffrey. Crimes Against Humanity: The Struggle for Global Justice. Penguin Book. 2002

[35] Schmalleger, Frank. Criminology Today: An Integrative Introduction. New Jersey: Pearson Education Inc. 2006

[36] Santoso, Edy Yusuf Nur Samsu. Amuk Massa. Yogyakarta: Alief Press. 2004 
[37] Santoso, Thomas. Teori-teori Kekerasan. Jakarta: Ghalia. 2002

[38] Wignjosoebroto, Soetandyo. Dari Hukum Kolonial ke Hukum Nasional, Dinamika Sosial-Politik dalam Perkembangan Hukum di Indonesia. Jakarta. PT. Raja Grafindo Persada. 1994

[39] Wignjosoebroto, Soetandyo. Hukum: Paradigma, Metode, dan Dinamika Masalahnya.. Jakarta: ELSAM dan HUMA. 2002. 